\title{
Factors affecting postoperative hypocalcemia after thyroid surgery: Importance of incidental parathyroidectomy
}

\author{
Ibrahim Ali Ozemir, Mehmet Zeki Buldanli, Oktay Yener, Metin Leblebici, Tunc Eren, \\ Hakan Baysal, Orhan Alimoglu \\ Department of General Surgery, Istanbul Medeniyet University, Goztepe Training and Research Hospital, Istanbul, Turkey
}

\begin{abstract}
OBJECTIVE: The present study evaluated effects of incidental parathyroidectomy, surgical technique, and presence of thyroiditis or hyperthyroidism on occurrence of postoperative persistent or transient hypocalcemia.

METHODS: Patients who underwent thyroidectomy at İstanbul Medeniyet University between 2013 and 2015 were included in the study. Patient information, postoperative serum calcium levels, and pathology reports were investigated retrospectively. Group 1 was made up of patients who were found to have hypocalcemia (calcium $\leq 8.5 \mathrm{mg} / \mathrm{dL}$ ) according to postoperative serum level and normocalcemic patients were placed in Group 2. Groups were compared statistically in terms of rate of incidental parathyroidectomy, surgical technique, and presence of thyroiditis or hyperthyroidism.
\end{abstract}

RESULTS: Mean age was $49.8 \pm 12.8$ years (range: $20-88$ ). A total of 417 patients were included in the study, 74 $(17.7 \%)$ were male and $343(82.3 \%)$ were female. Group 1 consisted of 205 (49.2\%) patients who had hypocalcemia according to postoperative serum level, and remaining $212(50.8 \%)$ patients were placed in Group 2. In Group 1, 38 (18.5\%) patients had incidental parathyroidectomy, and with only 18 (8.5\%) patients in Group 2, a statistically significant relationship was found between incidental parathyroidectomy and hypocalcemia $(p=0.003)$. There was no statistically significant difference in terms of presence of thyroiditis or hyperthyroidism between groups. There was statistically significant decrease in postoperative hypocalcemia rate in patients with lobectomy compared to patients with bilateral total thyroidectomy or central neck dissection $(p<0.01)$.

CONCLUSION: Risk of postoperative hypocalcemia may be reduced with lobectomy for selected patients. In addition, delicate dissection during thyroidectomy is important in order to protect parathyroid glands and prevent hypocalcemia.

Keywords: Hypocalcemia; incidental parathyroidectomy; thyroidectomy.

Received: February 29, 2016 Accepted: March 15, 2016 Online: April 07, 2016

Correspondence: Dr. Ibrahim Ali OZEMIR. Kucuksu Mah., Asma Sok., Eston Kandilli Evleri Sitesi, A12 Blok, D: 8, Kandilli, Uskudar Istanbul, Turkey.

Tel: +90 5058032125 e-mail: draliozemir@hotmail.com

(c) Copyright 2016 by Istanbul Northern Anatolian Association of Public Hospitals - Available online at www.kuzeyklinikleri.com 
$\mathrm{T}$ hyroid surgery is accepted as a safe operation, and now has lower morbidity and satisfactory postoperative outcomes resulting in a shorter hospital stay. It is even performed as day surgery. $[1,2]$ Thyroidectomy is a widely performed operation in the practice of general surgery and has a complication rate lower than $5 \%$. Most frequently, postoperative hypocalcemia has been observed. Based on literature reviews, temporary, and permanent hypocalcemia are seen in $1.6-50 \%$, and $1.5-4 \%$ of cases, respectively [3, 4]. Since postoperative hypocalcemia requires calcium replacement and monitoring of serum calcium levels, it leads to prolongation of hospital stay and ensuing increase in hospital expenditures [3]. Trauma to 1 or more parathyroid glands or vasculature during thyroidectomy, or incidental removal of parathyroid gland with the specimen may lead to development of postoperative hypocalcemia. Etiological considerations include postoperative alkalosis-induced hypocalcemia resulting from hyperventilation triggered by postoperative pain, and dilutional hypocalcemia [5]. Incidental rate of parathyroid organs in thyroidectomy specimens have been reported to range between $6.4-31 \%[6,7]$.

In this study, factors related to the patient as well as surgical methods have been analyzed in the development of postoperative hypocalcemia, and importance and outcomes of incidental parathyroidectomy have been evaluated.

\section{MATERIALS AND METHODS}

Patients with various indications who had undergone thyroidectomy in general surgery clinic of Istanbul Medeniyet University between January 2013 and January 2015 were included in the study. Patients who had undergone combined thyroidectomy-parathyroidectomy operation with indication of primary hyperparathyroidism were excluded. Demographic data; preoperative serum T3 hormone, T4 hormone, thyroid-stimulating hormone (TSH), anti-thyroid peroxidase antibody (anti-TPO), and anti-thyroglobulin values; diagnoses; surgical notes; histopathology reports; and postoperative 24-hour serum calcium levels were recorded and evaluated retrospectively. Patients with postoperative calcium levels of $\leq 8.5 \mathrm{mg} / \mathrm{dL}$ were considered hypocalcemic (Group 1). The patients in Group 1 were divided into subgroups of manifest hypocalcemia (serum calcium $<8.0 \mathrm{mg} / \mathrm{dL}$ ) and mild hypocalcemia (serum calcium $8.1-8.5 \mathrm{mg} / \mathrm{dL}$ ). Presence of hyperthyroidism was determined based on results of the preoperative thyroid function tests, while presence of thyroiditis was assessed based on histopathology reports and preoperative antibody levels. Surgical methods used were compared between groups and statistically evaluated for rate of incidental parathyroiditis.

This study was realized in compliance with World Medical Association Declaration of Helsinki: ethical principles for medical research involving human subjects. Approval of the ethics committee, and informed written consent of patients was obtained.

\section{Statistical analysis}

Statistical analysis of data was performed using SPSS software (version 20.0; SPSS Inc., Chicago, IL, USA). Pearson's chi-squared test or Fisher's exact test was used to compare qualitative nonparametric variables, and for comparison of 3 or more than 3 independent variables, one-way analysis of variance (ANOVA) test was used. To compare quantitative data, Mann-Whitney $U$ test was used. Level of statistical significance was determined at $\mathrm{p}<0.05$.

\section{RESULTS}

A total of 417 patients who had undergone thyroidectomy due to various indications were included in the study. Study population consisted of 74 (17.7\%) male and 343 (82.3\%) female patients with an overall mean age of $49.8 \pm 12.8$ (range: $20-88$ years). At postoperative 24 hours, 205 (49.2\%) patients with serum calcium levels of $\leq 8.5 \mathrm{mg} / \mathrm{dL}$ were accepted as hypocalcemic, and classified as Group 1. The remaining 212 patients with serum calcium levels of $>8.5 \mathrm{mg} / \mathrm{dL}$ were considered normocalcemic and placed in Group 2. Mean age of patients in Group 1 was 50.2 \pm 13.1 years, and in Group 2 it was $49.3 \pm 12.7$ years. No intergroup difference was found with respect to patient age $(p>0.05)$. In 
Group 1, there were 64 (31.2\%) patients with thyroiditis and $44(21.5 \%)$ with hyperthyroidism; in Group 2, there were 58 (27.4\%) with thyroiditis and $41(19.3 \%)$ with hyperthyroidism. No statistically significant intergroup difference was found with respect to the presence of thyroiditis or hyperthyroidism (Table 1). Incidental parathyroidectomy was noted in a total of $56(13.4 \%)$ patients: $38(18.5 \%)$ in Group 1, and 18 (8.5\%) cases of incidental parathyroidectomy were found in Group 2. A statistically significant correlation was not found between incidental parathyroidectomy and development of postoperative hypocalcemia $(p=0.003)$. Patients were divided into subgroups according to the number of incidentally excised parathyroid glands. No statistically significant difference was found between development of hypocalcemia and excision of 1 or 2 parathyroid glands (Table 1). Patients in Groups 1 and 2 were also divided into 4 subgroups based on type of operation performed: lobectomy, bilateral total thyroidectomy, recurrent thyroidectomy, and central dissection. A statistically significant difference was detected between the 2 groups as far as surgery performed. Post hoc analysis revealed a significant difference between patients who had under- gone central dissection and lobectomy regarding development of postoperative hypocalcemia (Table 1 ).

In $102(49.3 \%)$ patients in Group 1, serum calcium levels of between $8.1-8.5 \mathrm{mg} / \mathrm{dL}$ comprised subgroup of mild hypocalcemia, while 104 (50.7\%) patients with calcium levels of $\leq 8.0 \mathrm{mg} / \mathrm{dL}$ constituted subgroup of manifest hypocalcemia. Presence of thyroiditis, hyperthyroidism and rate of incidental parathyroidectomy between these 2 subgroups were not statistically significantly different (Table 2). When type of operation performed was compared, statistically significant increase in development of manifest hypocalcemia was seen in patients who underwent central dissection compared to lobectomy.

Six (1.4\%) hypocalcemic patients receiving calcium and vitamin $D$ replacement therapy at 1 year into follow-up period were considered to have permanent hypocalcemia. Three (50\%) had undergone central dissection, and a significant correlation was detected between central dissection and permanent hypocalcemia (Table 3 ).

\section{DISCUSSION}

Thyroid diseases have an important place among

TABLE 1. Comparison of development of hypocalcemia and incidental parathyroidectomy, presence of thyroiditis, hyperthyroidism, type of surgery performed in patient groups with and without hypocalcemia

\begin{tabular}{|c|c|c|c|c|c|c|c|}
\hline & \multicolumn{2}{|c|}{$\begin{array}{l}\text { Group 1 } \\
(n=205)\end{array}$} & \multicolumn{2}{|c|}{$\begin{array}{l}\text { Group } 2 \\
(n=212)\end{array}$} & \multicolumn{2}{|c|}{$\begin{array}{c}\text { Total } \\
(n=417)\end{array}$} & \multirow[t]{2}{*}{$\mathrm{p}$} \\
\hline & $\mathrm{n}$ & $\%$ & $\mathrm{n}$ & $\%$ & $\mathrm{n}$ & $\%$ & \\
\hline Thyroiditisa & 64 & 31.2 & 58 & 27.4 & 122 & 29.3 & NS. \\
\hline Hyperthyroidism a & 44 & 21.5 & 41 & 19.3 & 85 & 20.4 & NS \\
\hline Incidental parathyroidectomy $(+)^{a}$ & 38 & 18.5 & 18 & 8.5 & 56 & 13.4 & $0.003^{*}$ \\
\hline 1 parathyroid gland ${ }^{a}$ & 30 & 14.6 & 16 & 7.5 & 46 & 11 & NS \\
\hline 2 parathyroid glandr & 8 & 3.9 & 2 & 1 & 10 & 2.4 & NS \\
\hline Type of operation ${ }^{\beta}$ & & & & & & & $<0.001^{*}$ \\
\hline Lobectomy $^{a}$ & 26 & 12.7 & 56 & 26.4 & 82 & 19.7 & $<0.001^{*}$ \\
\hline Bilateral total thyroidectomy ${ }^{a}$ & 144 & 70.2 & 140 & 66 & 284 & 68.1 & NS \\
\hline Secondary thyroidectomy ${ }^{a}$ & 13 & 6.3 & 9 & 4.2 & 22 & 5.3 & NS \\
\hline Central dissection ${ }^{a}$ & 22 & 10.7 & 7 & 3.3 & 29 & 6.9 & $0.002^{*}$ \\
\hline
\end{tabular}

a: Pearson's chi-squared test; $\beta$ : One-way analysis of variance (ANOVA) test; $ү$ : Fisher's exact test; *: Level of statistical significance: $p<0.01$; NS: Not significant. 
TABLE2. In subgroups of mild and manifest hypocalcemia, comparison of incidental parathyroidectomy, presence of thyroiditis, hyperthyroidism, and type of surgery performed

\begin{tabular}{|c|c|c|c|c|c|}
\hline & \multicolumn{2}{|c|}{$\begin{array}{c}\text { Mild hypocalcemia } \\
(8.1-8.5 \mathrm{mg} / \mathrm{dL})(\mathrm{n}=101)\end{array}$} & \multicolumn{2}{|c|}{$\begin{array}{l}\text { Manifest hypocalcemia } \\
(\leq 8.0 \mathrm{mg} / \mathrm{dL})(\mathrm{n}=104)\end{array}$} & \multirow[t]{2}{*}{$\mathrm{p}$} \\
\hline & $\mathrm{n}$ & $\%$ & $\mathrm{n}$ & $\%$ & \\
\hline Thyroiditisa & 29 & 31.5 & 35 & 32.5 & NS \\
\hline Hyperthyroidism $^{a}$ & 44 & 21.5 & 41 & 19.3 & NS \\
\hline Incidental parathyroidectomy $(+)^{a}$ & 15 & 14.9 & 23 & 22.1 & NS \\
\hline 1 parathyroid gland ${ }^{a}$ & 14 & 13.9 & 16 & 15.4 & NS \\
\hline 2 parathyroid glandr & 1 & 1 & 7 & 6.7 & NS \\
\hline Type of operation ${ }^{\beta}$ & & & & & $<0.00^{1 *}$ \\
\hline Lobectomy ${ }^{a}$ & 20 & 19.8 & 6 & 5.8 & $<0.001^{*}$ \\
\hline Bilateral total thyroidectomy ${ }^{a}$ & 67 & 66.3 & 77 & 74.1 & NS \\
\hline Secondary thyroidectomy ${ }^{a}$ & 9 & 8.9 & 4 & 3.8 & NS \\
\hline Central dissection ${ }^{a}$ & 5 & 5 & 17 & 16.3 & $<0.05^{* *}$ \\
\hline
\end{tabular}

a: Pearson's chi-squared test; $\beta$ : One way analysis of variance (ANOVA) test; $ү$ : Fisher's exact test; *: Level of statistical significance: $p<0.01 ; * *$ : Level of statistical significance: $p<0.05$; NS: Not significant.

TABLE 3. At postoperative one year check, comparison of normocalcemic patients with six patients who were receiving treatment for permanent hypocalcemia

\begin{tabular}{|c|c|c|c|c|c|}
\hline & \multicolumn{2}{|c|}{ Normocalcemia $(n=411)$} & \multicolumn{2}{|c|}{ Permanent Hipocalcemia $(n=6)$} & \multirow[t]{2}{*}{$\mathrm{p}$} \\
\hline & $\mathrm{n}$ & $\%$ & $\mathrm{n}$ & $\%$ & \\
\hline Thyroiditisa & 119 & 28.9 & 3 & 50 & NS \\
\hline Hyperthyroidism $^{a}$ & 84 & 20.4 & 1 & 16.7 & NS \\
\hline Incidental parathyroidectomy $(+)^{\mathrm{a}}$ & 53 & 12.9 & 3 & 50 & NS \\
\hline 1 parathyroid gland ${ }^{a}$ & 44 & 10.7 & 2 & 33.3 & NS \\
\hline 2 parathyroid glandr & 9 & 2.2 & 1 & 16.7 & NS \\
\hline Type of operation ${ }^{\beta}$ & & & & & - \\
\hline Lobectomy ${ }^{a}$ & 20 & 19.8 & - & - & - \\
\hline Bilateral total thyroidectomy ${ }^{a}$ & 67 & 66.3 & 3 & 50 & NS \\
\hline Secondary thyroidectomy ${ }^{a}$ & 9 & 8.9 & - & - & - \\
\hline Central dissection ${ }^{a}$ & 3 & 5 & 3 & 50 & $<0.001^{*}$ \\
\hline
\end{tabular}

y: Fisher's exact test; *: Level of statistical significance $p<0.01 ; * *$ : Level of statistical significance $p<0.05$; NS: Not significant.

endocrine disorders, and thyroid gland surgery is the most frequently performed endocrine surgery [8]. Thyroidectomy is now performed by experienced endocrine surgeons and morbidity rates are lower. The most frequently seen complication following thyroidectomy is temporary or permanent hypocalcemia, which can impair quality of life [5] and prolong hospital stay. In the literature, both temporary and permanent hypocalcemia have been reported in $1.6-50 \%$ and $1.5-4 \%$ of cases, respectively $[3,4]$. The most important factors influencing postoperative development of hypocalcemia 
include, intraoperative trauma to parathyroid gland or its vasculature, inability to identify parathyroid gland during operation, incidental parathyroidectomy, and experience of the surgeon $[5,9,10,11]$. Variations in the number and anatomical location of parathyroid glands increase risk of incidental parathyroidectomy [12]. In studies, rates of incidental parathyroidectomy were reported to range between $6.4-19.7 \%[6,13]$. Thyroid surgeries of the present study were performed by experienced surgeons who do at least 50 thyroidectomies a year, and incidental parathyroidectomy rate is estimated at $13.4 \%$, within the rates cited in the literature. In a study performed by Özoğul et al,, it was reported that the risk of incidental parathyroidectomy and related postoperative hypocalcemia was higher in thyroidectomies performed because of presence of malignancy and in patients who had undergone neck dissection in compliance with oncological principles $[3,7]$. In the same study, a statistically significant correlation was detected between incidental parathyroidectomy, and hypocalcemia. In studies performed by Bergenfelz et al. [10], authors reported that this correlation was independent of extent of thyroidectomy and neck dissection. It has also been indicated that routine use of autotransplantation will be useful in postoperative examination of the specimen and identification of parathyroid gland [14]. Sasson et al. [15] detected a significant correlation between incidental parathyroidectomy and postoperative hypocalcemia. In the present study, statistically significant higher incidence of hypocalcemia was found in groups of patients who had undergone central dissection and incidental parathyroidectomy. In studies performed on parathyroid gland damage and incidental parathyroidectomy, authors have reported correlations between onset and longevity of hypocalcemic symptoms and the number of extracted and damaged parathyroid glands $[16,17]$. However in the present study, a statistically significant difference was not found in incidence of hypocalcemia between patients in whom 1 or 2 parathyroid glands were extirpated.

In the literature, contrary opinions have been asserted about correlations between development of postoperative hypocalcemia and patient age. In some studies, advanced age group [18], and in other studies younger age group [11] were found to be at risk. In a review of 2576 patients performed by Edafe et al., no difference in development of hypocalcemia based on age [19]. The present study also found no significant intergroup difference with regard to age of patients.

In patients with hyperthyroidism, difficulties encountered during surgery because of complex vascularity of thyroid gland have also been evaluated as a risk factor for development of hypocalcemia. Zambudio et al. [20] found presence of hyperthyroidism to be an independent risk factor for development of hypocalcemia. Contradictory publications are found in the literature [3]. In the present study, no correlation was seen between hyperthyroidism and risk of hypocalcemia. Various studies have found a number of factors that increase risk of permanent hypocalcemia including, extent of surgical resection, total parathyroidectomy, recurrent goiter, secondary surgeries, identification of fewer than 2 parathyroid glands, incidental parathyroidectomy, and surgical inexperience [21, 22, 23, 24].

Unless surgeons have ample experience with parathyroid glands and vascularization can be preserved using capsular dissection, routine exploration of all 4 parathyroid glands is not recommended $[5,25,26,27]$. It has been noted that in $83 \%$ of cases, parathyroid glands with impaired nutrient supply or autotransplanted dissected glands with intact capsules retained their biochemical activity [28].

In conclusion, this study has shown that incidental parathyroidectomy, bilateral thyroidectomy, and central dissection significantly increase the risk of developing postoperative hypocalcemia. Intraoperative identification of parathyroid glands is recommended. Any part removed should be analyzed to reveal incidental parathyroidectomy, and autotransplantation should be performed when needed to decrease risk of postoperative hypocalcemia. Similarly, in indicated cases, limited surgery, preferably lobectomy, and meticulous dissection in patients with more extensive surgery will decrease rates of incidental parathyroidectomy and development of postoperative hypocalcemia. 
Conflict of Interest: No conflict of interest was declared by the authors.

Financial Disclosure: The authors declared that this study has received no financial support.

Authorship contributions: Concept - İ.A.Ö; Design - İ.A.Ö; Supervision - İ.A.Ö, T.E.; Materials - M.Z.B., O.Y., M.L.; Data collection and/or processing - M.Z.B., O.Y., M.L.; Analysis and/ or interpretation - İ.A.Ö, T.E., H.B., O.A.; Literature search Writing - İ.A.Ö, T.E.; Critical review - İ.A.Ö, T.E., O.A.

\section{REFERENCES}

1. Koyuncu A, Dökmetas HS, Turan M, Aydin C, Karadayi K, Budak E, et al. Comparison of different thyroidectomy techniques for benign thyroid disease. Endocr J 2003;50:723-7. Crossref

2. Sun GH, DeMonner MM. Epidemiological and economic trends in impatient and outpatient thyroidectomy in the United States, 1996-2006. Thyroid 2013;23:727-33. Crossref

3. Noureldine SI, Genther DJ, Lopez M, Agrawal N, Tufano RP. Early Predictors of Hypocalcemia After Total Thyroidectomy: An Analysis of 304 Patients Using a Short-Stay Monitoring Protocol, JAMA Otolaryngol Head Neck Surg 2014;140:1006-13.

4. Pattou F, Combermale F, Fabre S, Carnaille B, Decoulx M, Wemeau JL, et al. Hypocalcemia following thyroid surgery: incidence and prediction of outcome. World J Surg 1998;22:71824. Crossref

5. Uludağ M. Tiroid ve paratiroid cerrahisi sonrası hipokalsemi ve tedavisi. ŞEEAH Tip Bülteni 2014;48:161-75.

6. Erbil Y, Barbaros U, Ozbey N, Aral F, Ozarmağan S. Risk factors of incidental parathyroidectomy after thyroidectomy for benign thyroid disorders. Int J Surg 2009;7:58-61. Crossref

7. Özoğul B, Akçay MN, Kısaoğlu A, Atamanalp SŞ, Öztürk G, Aydinl 1 B. Incidental parathyroidectomy during thyroid surgery: risk factors, incidence, and outcomes. Turk J Med Sci 2014;44:84-8. Crossref

8. Baldassarre RL, Chang DC, Brumund KT, Bouvet M. Predictors of hypocalcemia after thyroidectomy: results from the nationwide inpatient sample. ISRN Surg 2012;2012:838614. Crossref

9. Campos NS, Cardoso LP, Tanios RT, Oliveira BC, Guimarães AV, Dedivitis RA, Marcopito LF. Risk factors for incidental parathyroidectomy during thyroidectomy. Braz J Otorhinolaryngol 2012;78:57-61. Crossref

10. Bergenfelz A, Jansson S, Kristoffersson A, Mårtensson H, Reihnér $\mathrm{E}$, Wallin $\mathrm{G}$, et al. Complications to thyroid surgery: results as reported in a database from a multicenter audit comprising 3,660 patients. Langenbecks Arch Surg 2008;393:667-73. Crossref

11. Lang BH, Yih PC, Ng KK. A prospective evaluation of quick intraoperative parathyroid hormone assay at the time of skin closure in predicting clinically relevant hypocalcemia after thyroidectomy. World J Surg 2012;36:1300-6. Crossref

12. Abboud B. Topographic anatomy and arterial vascularization of the parathyroid glands: practical application. Presse Med 1996;25:1156-61.

13. Sakorafas GH, Stafyla V, Bramis C, Kotsifopoulos N, Kolettis
T, Kassaras G. Incidental parathyroidectomy during thyroid surgery: an underappreciated complication of thyroidectomy. World J Surg 2005;29:1539-43. Crossref

14. Olson JA Jr, DeBenedetti MK, Baumann DS, Wells SA Jr. Parathyroid autotransplantation during thyroidectomy. Results of long-term follow-up. Ann Surg 1996;223:472-8. Crossref

15. Sasson AR, Pingpank JF Jr, Wetherington RW, Hanlon AL, Ridge JA. Incidental parathyroidectomy during thyroid surgery does not cause transient symptomatic hypocalcemia. Arch Otolaryngol Head Neck Surg 2001;127:304-8. Crossref

16. Asari R, Passler C, Kaczirek K, Scheuba C, Niederle B. Hypoparathyroidism after total thyroidectomy. Arch Surg 2008;143:132-7. Crossref

17. Spiliotis J, Vaxevanidou A, Sergouniotis F, Tsiveriotis K, Datsis A, Rogdakis A, Kekelos S. Risk factors and consequences of incidental parathyroidectomy during thyroidectomy. Am Surg 2010;76:436-41.

18. Kamer E, Unalp HR, Erbil Y, Akguner T, Issever H, Tarcan E. Early prediction of hypocalcemia after thyroidectomy by parathormone measurement in surgical site irrigation fluid. Int J Surg 2009;7:466-71. Crossref

19. Edafe O, Antakia R, Laskar N, Uttley L, Balasubramanian SP. Systematic review and meta-analysis of predictors of post-thyroidectomy hypocalcaemia. Br J Surg 2014;101:307-20. Crossref

20. Zambudio Ar, Rodriguez J, Riquelme J, Soria T, Canteras M, Parilla P. Prospective study of postoperative complications after total thyroidectomy for multinodular gaiters by surgeons with experience in endocrine surgery. Ann Syrg 2004;240:18-25. Crossref

21. Karamanakos SN, Markou KB, Panagopoulos K, Karavias D, Vagianos CE, Scopa CD, et al. Complications and risk factors related to the extent of surgery in thyroidectomy. Results from 2,043 procedures. Hormones (Athens) 2010;9:318-25. Crossref

22. Paek SY, Lee YM, Min SY, Kim SW, Chung KW, Youn YK. Risk factors of hypoparathyroidism following total thyroidectomy for thyroid cancer. Worl J Surg 2013;37:94-101. Crossref

23. Thomusch O, Machens A, Sekulla C, Ukkat J, Brauckhoff M, Dralle $H$. The impact of surgical technique on postoperative hypoparathyroidism in bilateral thyroid surgery: a multivariate analysis of 5846 consecutive patients. Surgery 2003;133:180-5.

24. Burge MR, Zeise TM, Johnsen MW, Conway MJ, Qualls CR. Risks of complication following thyroidectomy. J Gen Intern Med 1998;13:24-31. Crossref

25. Yetkin E, Makay Ö. Tiroidektomi komplikasyonları: Genel bakış. In: İşgör A, Uludağ M, editör. Tiroid. 1. Baskı. İstanbul: Nobel Tip Kitabevleri; 2013. s. 941-54.

26. Delbridge L, Reeve TS, Khadra M, Poole AG. Total thyroidectomy: the technique of capsular dissection. Aust N Z J Surg 1992;62:96-9. Crossref

27. Sheahan P, Mehanna R, Basheeth N, Murphy MS. Is systematic identification of all four parathyroid glands necessary during total thyroidectomy?: a prospective study. Laryngoscope 2013;123:2324-8. Crossref

28. Sierra M, Herrera MF, Herrero B, Jiménez F, Sepúlveda J, Lozano RR, et al. Prospective biochemical and scintigraphic evaluation of autografted normal parathyroid glands in patients undergoing thyroid operations. Surgery 1998;124:1005-10. Crossref 